\title{
Artikel
}

\section{De regeling van de schriftelijke wilsverklaring euthanasie in artikel 2 lid 2 Wtl}

Mr. dr. L. (Liselotte) Postma*

\section{NTS 2021/57}

\section{Inleiding}

Een ander opzettelijk het leven benemen is in Nederland in beginsel strafbaar, ook als de levensbeëindiging op verzoek van de betrokkene heeft plaatsgevonden. Sinds de inwerkingtreding van de Wet toetsing levensbeëindiging op verzoek en hulp bij zelfdoding (Wtl) op 1 april 2002 kan een arts na levensbeëindigend handelen op verzoek een beroep doen op de bijzondere strafuitsluitingsgrond van artikel 293 lid 2 van het Wetboek van Strafrecht (Sr). ${ }^{1}$ Het is voor een gegrond beroep noodzakelijk dat de arts zijn levensbeëindigend handelen heeft gemeld bij de gemeentelijk lijkschouwer en de zorgvuldigheidseisen van artikel 2 lid $1 \mathrm{Wtl}$ in acht heeft genomen. Deze zorgvuldigheideisen houden in dat de arts de overtuiging heeft gekregen van een vrijwillig en weloverwogen verzoek (a) en overtuigd is van uitzichtloos en ondraaglijk lijden van de patiënt (b). De arts dient de patiënt te hebben voorgelicht over de situatie en diens vooruitzichten (c) en met de patiënt tot de overtuiging te zijn gekomen dat er voor de situatie waarin deze zich bevond geen redelijke andere oplossing was (d). Voorts dient de arts ten minste één andere, onafhankelijke arts te hebben geraadpleegd, die de patiënt heeft gezien en schriftelijk zijn oordeel heeft gegeven over de zorgvuldigheidseisen (e). De laatste eis (f) luidt dat de levensbeëindiging medisch zorgvuldig is uitgevoerd.

Het merendeel van de ingewilligde euthanasieverzoeken heeft betrekking op een actueel verzoek tot levensbeëindiging van een meerderjarige, wilsbekwame patiënt die ondraaglijk en uitzichtloos lijdt aan een somatische ziekte. ${ }^{2}$ Zoals onder meer blijkt uit de meest recente evaluatie van de Wtl, leidt de euthanasiewetgeving in een dergelijke 'standaard-situatie' niet of nauwelijks meer tot discussie. De Wtl werkt in principe goed. ${ }^{3}$ Anders geldt dat voor enkele bijzondere categorieën van levensbeëindiging op verzoek, waarvan euthanasie op basis van een schriftelijke wilsverklaring er één is.

Een arts heeft op grond van artikel 2 lid $2 \mathrm{Wtl}$ de mogelijkheid euthanasie toe te passen bij een inmiddels wilsonbekwame patiënt op basis van een 'schriftelijke wilsverklaring euthanasie'. Deze bepaling luidt als volgt:

'Indien de patiënt van zestien jaren of ouder niet langer in staat is zijn wil te uiten, maar voordat hij in die staat geraakte tot een redelijke waardering van zijn belangen terzake in staat werd geacht, en een schriftelijke verklaring, inhoudende een verzoek om levensbeëindiging, heeft afgelegd, dan kan de arts aan dit verzoek gevolg geven. De zorgvuldigheidseisen,
* Mr. dr. L. (Liselotte) Postma is universitair docent strafrecht en strafprocesrecht aan de Erasmus Universiteit Rotterdam.

1. Wet toetsing levensbeëindiging op verzoek en hulp bij zelfdoding, $S t b$. 2001, 194 (inwerkingtreding Stb. 2002, 165). Deze bijzondere strafuitsluitingsgrond geldt ook in het geval van hulp bij zelfdoding door artsen (art. 294 lid 2 Sr).
2. Zoals alleen al blijkt uit de EuthanasieCode 2018 (herziene versie 2020) van de RTE, te raadplegen via: www.euthanasiecommissie.nl.

3. B.D. Onwuteaka-Philipsen, J. Legemaate, A van der Heide e.a., Derde evaluatie toetsing levensbeëindiging op verzoek en hulp bij zelfdoding, Den Haag: ZonMw 2017, p. 253-255. 
bedoeld in het eerste lid, zijn van overeenkomstige toepassing.'

Levensbeëindiging op basis van artikel 2 lid $2 \mathrm{Wtl}$ komt in de praktijk nauwelijks voor. Blijkens het meest recente jaarverslag van de Regionale Toetsingscommissies Euthanasie (RTE) hadden in 2020 slechts 2 van de in totaal 6.938 euthanasiemeldingen betrekking op euthanasie op basis van een schriftelijke wilsverklaring (bij gevorderde dementie). ${ }^{4}$ Cijfers van voorgaande jaren tonen hetzelfde beeld. Behoefte aan de mogelijkheid om tot euthanasie over te kunnen gaan op basis van een schriftelijke wilsverklaring is er wel. Naar schatting zal in 2040 een half miljoen Nederlanders een vorm van dementie hebben. ${ }^{5}$ Hoogleraar langdurige zorg en dementie The heeft in 2017 betoogd dat mensen na de diagnose van dementie regelmatig hun zelfgekozen dood willen regelen. Bij sommigen is die wens aangewakkerd of versterkt door het (zorgwekkende) beeld in de samenleving dat dementie onmenselijk lijden betekent waarvoor euthanasie de enige optie lijkt te zijn. ${ }^{6}$ De verwachting is dan ook dat steeds meer mensen een schriftelijke wilsverklaring zullen opstellen. Tegelijkertijd ligt de regeling van de schriftelijke wilsverklaring regelmatig onder vuur.

De regeling van de schriftelijke wilsverklaring in artikel 2 lid $2 \mathrm{Wtl}$ staat in deze bijdrage, die deels is gebaseerd op het proefschrift waarop de auteur van het onderhavige artikel op 1 april 2020 is gepromoveerd, centraal. $^{7}$ Het standpunt wordt verdedigd dat de wettelijke modaliteit van regeling van de schriftelijke wilsverklaring via de enkele bewoordingen in artikel 2 lid $2 \mathrm{Wtl}$ dat de zorgvuldigheidseisen bedoeld in het eerste lid 'van overeenkomstige toepassing' zijn, niet houdbaar is. Daarvoor wordt zowel de ontstaansgeschiedenis van de regeling als de huidige stand van zaken omtrent euthanasie op basis van een schriftelijke wilsverklaring, onder de loep genomen. In het eerste deel van deze bijdrage staat de periode voor de inwerkingtreding van de Wtl centraal: de opkomst van het fenomeen 'schriftelijke wilsverklaring euthanasie' (par. 2), de ontwikkeling van de strafuitsluitingsgrond en bijbehorende zorgvuldigheidseisen in de jurisprudentie (par. 3), het advies van de Staatscommissie Euthanasie uit 1985 (par. 4.) en de parlementaire geschiedenis van artikel 2 lid $2 \mathrm{Wtl}$ (par. 5). In paragraaf 6 volgt een uitstapje naar de regeling van de schriftelijke wilsverklaring in België. Vervolgens komt in paragraaf 7 de huidige stand van zaken van de Nederlandse regeling aan bod, mede naar

4. RTE Jaarverslag 2020, p. 11 en 13, te raadplegen via www.euthanasiecommissie.nl.

5. Deltaplan dementie 2012-2020, www.neurodegenerationresearch.eu/ wp-content/uploads/2014/08/rapport-deltaplan-dementie.pdf, p. 5.

6. A. The, 'Ten geleide: zorg bij dementie', in: B. Chabot, De weg kwijt. De zorgelijke staat van de euthanasiewet, Amsterdam: Nijgh \& Van Ditmar 2017, p. 12.

7. L. Postma, Misschien was het nog te vroeg. De regeling van de schriftelijke wilsverklaring euthanasie in artikel 2, tweede lid, WtI vanuit een strafrechtelijk perspectief (diss. Rotterdam), Den Haag: Boom juridisch 2021. aanleiding van de uitspraken van de Hoge Raad van 21 april 2020 met betrekking tot euthanasie bij dementie. ${ }^{8}$ De bijdrage sluit af met de noodzaak tot wijziging van de regeling naar een adequate(re) modaliteit en een concreet voorstel daartoe.

\section{Opkomst van een fenomeen}

De grondslag van de Nederlandse euthanasiewetgeving ligt in artikel $293 \mathrm{Sr}$ waarin levensbeëindiging op uitdrukkelijk en ernstig verlangen van de betrokkene sinds 1886 strafbaar is gesteld. Hoewel het verzoek de levensbeëindiging wel een ander karakter gaf dan moord of doodslag, was de wetgever destijds van mening dat 'toestemming' van de betrokkene de strafbaarheid van het levensbeëindigend handelen niet zonder meer kon opheffen. ${ }^{9}$ Doorslaggevend was de eerbied voor het menselijk leven in het algemeen. Het klassieke beginsel volenti non fit inuria, inhoudende dat er slechts een delict bestaat als de wil van het individu wordt geschonden, ging (en gaat) wat betreft euthanasie derhalve niet op. ${ }^{10}$ Behoudens de algemene strafuitsluitingsgronden die het Wetboek van Strafrecht kende, bestond er van 1886 tot 2002 in principe geen uitzondering op de strafbaarheid van levensbeëindiging op verzoek. Euthanasie speelt zich doorgaans af in de context van een arts-patientrelatie. Tot aan het eind van de jaren zestig van de vorige eeuw gold 'de absolute eerbied voor het menselijk leven' als richtlijn voor medisch handelen. ${ }^{11}$ Daarmee is niet gezegd dat euthanasie in het geheel niet voorkwam, er zijn aanwijzingen die op het tegendeel wijzen. ${ }^{12}$ In het algemeen gold dat een arts menselijk leven diende te behouden en te verlengen, waar en wanneer hij dat kon. Die opvatting had consequenties voor het denken over en uitvoering (willen c.q. mogen) geven aan euthanasie. $^{13}$

Als gevolg van de enorme toename van (medische) technologieën ontstond vanaf de jaren zestig van de vorige eeuw een discussie over de grenzen van medisch handelen. De medisch-technische ontwikkeling werd enerzijds beschouwd als iets positiefs. Mensen konden langer in leven blijven en het was meer dan voorheen

8. HR 21 april 2020, ECLI:NL:HR:2020:712 en HR 21 april 2020, ECLI:NL:HR:2020:713

9. H.J. Smidt, Geschiedenis van het wetboek van strafrecht, Haarlem: H.D. Tjeenk Willink 1891, p. 463.

10. A.R. Baas, Levensberooving op verzoek en zelfmoord (artt. 293 en 294 W.v.S.) (diss. Amsterdam VU) Amsterdam: Portielje 1910, p. 53 en S.R. Bakker \& L. Postma, 'Volenti non fit iniuria', Strafblad 2019, afl. 3.

11. H.A.H. van Till-d'Aulnis de Bourouill, Medisch-juridische aspecten van het einde van het menselijk leven (diss. Universiteit Leiden), 1970, p. 26-27 en P. Muntendam (red.), Euthanasie, Leiden: Stafleu's wetenschappelijke uitgeversmaatschappij 1977, p. 6.

12. Zie o.a. H.W.A. Hilhorst, Euthanasie in het ziekenhuis. De 'zachte dood' bij ziekenhuispatiënten, Lochem/Poperinge: Uitgeversmaatschappij De Tijdstroom 1983, p. 133 en A. The, Verlossers naast god. Dokters en euthanasie in Nederland, Amsterdam: Uitgeverij Thoeris 2009, m.n. p. 33 e.v.

13. J.H. van den Berg, Medische macht en medische ethiek, Nijkerk: Callenbach 1969, p. 7. 
mogelijk om te genezen van ernstige ziektes. In de meeste gevallen was dat in het voordeel van de patiënt. Anderzijds bracht deze ontwikkeling mee dat patiënten hun arts steeds vaker verzochten om een 'zachte dood': de mogelijkheid om een 'leven' te verlengen werd door de patiënt in bepaalde gevallen als ondraaglijk ervaren. ${ }^{14}$ Langzamerhand werd de mogelijkheid om een behandeling achterwege te laten, te staken of een leven zelfs actief te beëindigen in de medische ethiek als reële optie beschouwd. De opvatting dat de arts niet alleen de taak had om leven in stand te houden, maar lijden van patiënten diende te verzachten kreeg door de jaren heen steeds meer steun. ${ }^{15}$ Bovendien werd het vanaf de jaren zestig niet langer als vanzelfsprekend beschouwd dat een arts als autoriteit kon beslissen wat er met de patiënt moest gebeuren. Patiënten wilden meer zelf de regie krijgen, zowel op het gebied van afzien van (verdere) levensverlengende behandelingen, als de vraag om zo spoedig mogelijk te sterven. ${ }^{16}$ De opkomst van het fenomeen schriftelijke wilsverklaring waarin patiënten wensen opstellen voor een mogelijke, toekomstige situatie waarin passief dan wel actief handelen van een arts verzocht werd, is hiermee in lijn.

Het 'Leeuwarder Euthanasieproces', waarin huisarts Postma in 1973 was veroordeeld tot een voorwaardelijke gevangenisstraf van een week wegens levensbeëindiging van haar oude, ernstig zieke moeder, op haar nadrukkelijke verzoek (art. $293 \mathrm{Sr}$ ), gaf een extra impuls aan de opkomst van de schriftelijke wilsverklaring in Nederland. ${ }^{17}$ Verontwaardiging over de vervolging en veroordeling van huisarts Postma leidde in de jaren zeventig van de vorige eeuw tot de oprichting van diverse verenigingen die zich inzetten voor 'straffeloze euthanasie' 18 Deze verenigingen wilden aan de wetgever laten zien dat er behoefte tot wijziging van 'die oude wet uit 1886' was, door hun leden de mogelijkheid te bieden schriftelijke milsverklaringen euthanasie op te stellen en te registreren en zodoende aan te kunnen tonen dat een grote groep Nederlanders een duurzaam euthanasieverzoek had. ${ }^{19}$ Vermoedelijk was het idee om dergelijke verklaringen te verspreiden afkomstig uit Engeland en de Verenigde Staten, waar de Voluntary Euthanasia Society respectievelijk de Euthanasia Educational Council toentertijd al jaren model-verklaringen voor vrijwillige euthanasie

14. Zie o.a. H.J.J. Leenen, Rechten van mensen in de gezondheidszorg. Een gezondheidsrechtelijke studie, Samsom Uitgeverij: Alphen aan den Rijn/Brussel 1978, p. 208 en Kamerstukken I/ 1983/84, 18331 nr. 3, p. 5.

15. Van Till-d'Aulnis de Bourouill 1970; P.J. Roscam Abbing, Toegenomen verantwoordelijkheid. Veranderende ethiek rond euthanasie, eugenetiek en moderne biologie, Nijkerk: Callenbach 1972, p. 20; Leenen 1978 , p. 232; P.V. Admiraal, Verantwoorde euthanasie: handleiding voor artsen, Amsterdam: Nederlandse Vereniging voor Vrijwillige Euthanasie 1980.

16. KNMG, 'Discussienota van de Werkgroep Euthanasie van de KNMG', MC 1975, 30, p. 7-8

17. Rb. Leeuwarden 21 februari 1973, ECLI:NL:RBLEE:1973:AB5464, NJ 1973/183

18. Leeuwarder Courant 20 januari 1973, p. 9, zie ook Th. Indewey Gerlings-Huurman, Het Leeuwarder euthanasieproces, Nijkerk: Callenbach 1977, p. 42

19. Postma 2021, par. 2.10 beschikbaar stelden (zogenoemde living wills). ${ }^{20}$ In de Nederlandse variant van de schriftelijke wilsverklaring was zowel plaats voor het staken c.q. niet aanvangen van medische behandeling als voor een voorwaardelijk, toekomstig verzoek om levensbeëindiging aan een arts. Overeenstemming bestond over het gevolg van een verzoek tot staken of niet aanvangen van een behandeling: de arts zou een dergelijk verzoek in principe moeten opvolgen omdat medisch handelen zonder toestemming van de patiënt in beginsel niet geoorloofd is. ${ }^{21}$ De betekenis van de schriftelijke wilsverklaring euthanasie was jarenlang onzeker. Toch waren er vanaf de jaren zeventig naar schatting vele duizenden van deze verklaringen in omloop. ${ }^{22}$

\section{Ontwikkeling zorgvuldigheidseisen gericht op 'standaardsituatie'}

In de periode dat de schriftelijke wilsverklaring haar intrede deed, drong in de strafrechtelijke rechtspraak ter zake de ruimte voor de verschuiving van maatschappelijke opvattingen omtrent euthanasie ook door. In een arrest van 27 november 1984 (het zogenoemde 'Schoonheim-arrest') aanvaardde de Hoge Raad dat een arts ter zake van euthanasie een geldig beroep zou kunnen doen op de rechtvaardigingsgrond overmacht (art. $40 \mathrm{Sr}$ ) in het geval van een conflict van plichten. ${ }^{23}$ Aan de ene kant had de arts de plicht om de wet na te leven en geen handelingen te verrichten die het leven van een ander beëindigen. Anderzijds was er een plicht voor de arts om naar medisch-ethische normen en naar objectief medisch inzicht de patiënt ondraaglijk lijden te besparen. Volgens dit model is het beslissend of de toegepaste euthanasie naar objectief medisch inzicht, getoetst aan medisch-ethische normen, als een in noodtoestand verricht handelen is te beschouwen op basis waarvan de arts op een verantwoorde wijze tot een keuze is gekomen. Voor de invulling van de noodtoestand blijkt in geval van euthanasie dus veel ruimte te zijn voor opvattingen in de medische praktijk. Het model dat de Hoge Raad in 1984 heeft aanvaard, sluit naadloos aan op de zorgvuldigheidseisen die in de jurisprudentie van de feitenrechter en in samenspraak met de beroepsgroep in de periode daarvoor al vorm hadden gekregen. ${ }^{24}$

20. G.H.A. Schut, 'Euthanasie - een burgerrechtelijke benadering', RM Themis 1979, p. 353

21. Postma 2021, par. 2.9.1. Zie (sinds 1995, met de inwerkingtreding van de WGBO) ook: art. 7:450 lid 3 BW.

22. Postma 2021, p. 75 en par. 5.3.2.

23. HR 27 november 1984, ECLI:NL:HR:1984:AC8615, NJ 1985/106 m.nt. Th.W. van Veen.

24. Rb. Leeuwarden 21 februari 1973, ECLI:NL:RBLEE:1973:AB5464, NJ 1973/183; Rb. Rotterdam 1 december 1981, ECLI:NL:RBROT: 1981:AB7817, NJ 1982/63 en 'KNMG standpunt inzake Euthanasie', Medisch Contact 1984, 31, p. 990-1003. 
De jurisprudentie tot aan de inwerkingtreding van de Wtl ziet echter niet op euthanasie op basis van een schriftelijke wilsverklaring. Soms komt de wilsverklaring in de rechtspraak wel voor, maar enkel ter ondersteuning van een actueel, mondeling verzoek. De in de rechtspraak geformuleerde zorgvuldigheidscriteria zijn ontwikkeld voor de situatie dat een arts zich bevindt in een noodtoestand, vanwege de confrontatie met het euthanasieverzoek dat zijn patiënt door onmiddellijk ondraaglijk lijden doet. De wisselwerking tussen de (in een noodtoestand verkerende) arts en de patiënt met de actuele lijdenservaring staat daarin centraal. Gesteld kan worden dat het in de jurisprudentie ontworpen kader, het conflict van plichten in het geval van een noodsituatie die dringend en acuut is, niet verenigbaar is met de situatie waarin een arts geconfronteerd wordt met een schriftelijke wilsverklaring van een patiënt die zijn wil niet meer kan uiten. ${ }^{25}$ Anders dan voor de 'standaardeuthanasie-situatie' biedt de jurisprudentie van voor de Wtl geen solide basis voor euthanasie op grond van een schriftelijke wilsverklaring.

\section{De schriftelijke wilsverklaring als 'ondergeschoven kindje' (1985-1999)}

In 1982 is een Staatscommissie inzake Euthanasie ingesteld om uiteindelijk in 1985 advies uit te brengen aan de wetgever 'omtrent het toekomstige overheidsbeleid inzake euthanasie en het verlenen van hulp bij zelfdoding, in het bijzonder ten aanzien van wetgeving en wetstoepassing'. ${ }^{26}$ De primaire vraag die in het advies van de Staatscommissie centraal stond, was of artikel 293 Sr zodanig gewijzigd diende te worden dat onder voorwaarden euthanasie niet meer strafbaar zou zijn: het antwoord daarop luidde in het rapport bevestigend. Het is aannemelijk dat daarbij aansluiting is gezocht bij het 'Schoonheim-arrest' van de Hoge Raad van $1984 .{ }^{27}$ De Staatscommissie hield, blijkens de vergaderstukken, de stand van zaken in de jurisprudentie nauwlettend in de gaten en concludeerde mede naar aanleiding van de overwegingen van de Hoge Raad, dat de strafbaarstelling van artikel $293 \mathrm{Sr}$ in principe intact moest blijven. ${ }^{28}$ Vervolgens was de vraag voor de Staatscommissie, binnen het uitgangspunt dat de gedraging in beginsel strafbaar was, onder welke omstandigheden en onder welke voorwaarden de strafbaarheid van euthanasie zou kunnen worden opgeheven. Het verdiende geen aanbeveling om straffeloos uitvoeren van euthanasie op de medische exceptie te baseren, zo meende de com-

25. Postma 2021, par. 2.16 en 9.3. Zie ook HR 9 november 2004, ECLI:NL:HR:2004:AP1493， NJ 2005/217 m.nt. Buruma en HR 12 juli 2011, ECLI:NL:HR:2011:BP5967, NJ 2011/578 m.nt. Mevis.

26. Staatscommissie Euthanasie, Rapport van de Staatscommissie Euthanasie, deel 1 advies, 's-Gravenhage: Staatsuitgeverij 1985, p. 12.

27. HR 27 november 1984, ECLI:NL:HR:1984:AC8615.

28. Postma 2021, par. 3.7.1 missie, omdat een arts die euthanasie uitvoert dan slechts tuchtrechtelijk ter verantwoording kan worden geroepen. $^{29}$

Het bleek voor de Staatscommissie onvermijdelijk om zich tevens te buigen over het fenomeen schriftelijke wilsverklaring en de eventuele rechtskracht die de wilsverklaring zou moeten krijgen binnen de nieuw te formuleren euthanasiewetgeving. Van het voorstel van een van de commissieleden om een oordeel van de rechter over deze kwestie af te wachten, wilde de meerderheid van de commissie niets weten, vanwege het grote aantal schriftelijke wilsverklaringen dat op dat moment al in omloop was en de rechtsonzekerheid die erover bestond. ${ }^{30}$ De schriftelijke wilsverklaring werd gezien als middel om ongelijkheid te voorkomen tussen enerzijds patiënten met een euthanasieverzoek die hun wil wél konden uiten op het moment dat de situatie waarin de gewenste euthanasie zou moeten plaatsvinden zich voordeed, en anderzijds degenen die dat op dat moment niet meer konden. De keuze van de Staatscommissie om het voor een arts, onder strikte voorwaarden, mogelijk te maken gehoor te geven aan een schriftelijk euthanasieverzoek van een inmiddels wilsonbekwame patiënt, als zijnde een aanwijzing dat sprake is van een wil van de patiënt, had ook anders kunnen luiden. Bepaalde knelpunten die tijdens de vergaderingen zijn aangekaart, zoals de vraag welke zorgvuldigheidseisen zouden moeten gelden bij een wilsonbekwame patiënt, komen in het rapport van de Staatscommissie nauwelijks meer aan de orde. Het concept dat de Staatscommissie aanreikt voor de regeling van de schriftelijke wilsverklaring euthanasie, lift als het ware mee met de voor de arts voorgestelde bijzondere strafuitsluitingsgrond in het geval van een euthanasieverzoek van een wilsbekwame patiënt, terwijl er (op basis van de notulen van vergaderingen van de commissie) goede gronden zijn voor een andere benadering. ${ }^{31}$

In de periode na publicatie van het rapport van de Staatscommissie uit 1985 , zijn diverse rapporten en wetsvoorstellen verschenen omtrent euthanasie. Enerzijds overheerst daarin het idee dat een schriftelijke wilsverklaring als (uitdrukking van de) wil van de patiënt kon gelden en dat een arts gehoor zou moeten kunnen geven aan dit 'plaatsvervangende' verzoek van de patiënt. Daartegenover staat het idee dat levensbeëindiging op basis van een wilsverklaring raakvlakken heeft met levensbeëindiging zonder verzoek, hetgeen nader uitgezocht zou moeten worden. In de wetsvoorstellen waarin de schriftelijke wilsverklaring wél een plaats kreeg binnen de euthanasiewetgeving, bleek telkens weer het 'normale' toetsingskader voor wilsbekwame patiënten uitgangspunt te zijn. Knelpunten die zich ten aanzien van de zorgvuldigheidseisen in het kader van de schriftelijke wilsverklaring zouden kunnen voordoen, kregen nauwelijks aandacht.

\footnotetext{
29. Staatscommissie Euthanasie 1985, deel 1, p. 30-31.

30. Postma 2021, par. 3.13

31. Postma 2021, par. 3.13
} 
De Commissie Aanvaardbaarheid Levensbeëindigend handelen (CAL) uit de periode 1985-1997 is in feite de enige commissie geweest die de problematiek van de schriftelijke wilsverklaring op een adequate wijze heeft geadresseerd door te concluderen dat de zorgvuldigheidseisen geschreven zijn voor een andere situatie, namelijk de confrontatie met een patiënt die de omstandigheden waarin hij verkeert, ervaart als uitzichtloos en ondraaglijk lijden, en op basis van het ervaren van die situatie aangeeft niet langer meer te willen leven. Het vaststellen van (met name) het voldoen aan de eis van uitzichtloos en ondraaglijk lijden beschouwde de CAL terecht als problematisch indien een patiënt wilsonbekwaam was geworden. Volgens de CAL was in die situatie geen sprake van een evidente noodsituatie, zoals dat wel het geval kan zijn bij een actueel euthanasieverzoek van een wilsbekwame patiënt. Die vaststelling hoefde volgens de CAL vervolgens niet zonder meer te betekenen dat levensbeëindiging op basis van een schriftelijke wilsverklaring 'nimmer mag plaatsvinden'. ${ }^{32}$

Blijkens de verschillende adviezen en wetsvoorstellen was men het er telkens over eens dat er iets met die wilsverklaring moest gebeuren. Maar wat en hoe, bleef lange tijd onduidelijk. Het regelen van de standaardsituatie had prioriteit. Dat is op zich begrijpelijk, maar daardoor is de regeling van de schriftelijke wilsverklaring in de (voorzet tot) totstandkoming van een euthanasiewet een ondergeschoven kindje gebleken, met de nodige consequenties. $^{33}$ De verschillen tussen levensbeëindiging op verzoek bij een wilsbekwame patiënt en bij een wilsonbekwame patiënt op basis van een schriftelijke wilsverklaring zijn in (het denken over) een eventuele regeling - op de CAL na - nauwelijks aan bod gekomen. Het (eventuele) belang van eigen procedures en voorwaarden voor de bijzondere situatie van euthanasie op basis van een schriftelijke wilsverklaring is onvoldoende erkend.

\section{Parlementaire geschiedenis: aanleiding voor nadere discussie}

Op 6 augustus 1999 maakten de Minister van Volksgezondheid, Welzijn en Sport (Borst-Eilers) en de Minister van Justitie (Korthals) het wetsvoorstel dat uiteindelijk tot de Wtl heeft geleid aanhangig bij de StatenGeneraal. ${ }^{34}$ Op 1 april 2002 is de Wtl inclusief artikel 2 lid 2 in werking getreden. ${ }^{35}$ Enerzijds is de keuze van de wetgever om de schriftelijke wilsverklaring te 'erkennen'

$\mathrm{CAL}$, Medisch handelen rond het levenseinde bij wilsonbekwame patiënten, Houten: Bohn Stafleu Van Loghum 1997, m.n. p. 132-133, 137 en 208.

33. Postma 2021, par. 4.13 en 9.2

34. Kamerstukken II 1998/99, 26691, nr. 1-2

35. Wet van 12 april 2001 houdende toetsing van levensbeëindiging op verzoek en hulp bij zelfdoding en wijziging van het Wetboek van Strafrecht en van de Wet op de lijkbezorging (Wet toetsing levens- en mee te nemen in de euthanasiewetgeving, begrijpelijk. Er waren nu eenmaal zo veel wilsverklaringen in de maatschappij in omloop dat men er wel iets over moest zeggen. Anderzijds is deze keuze ook minder begrijpelijk doordat de discussie over een regeling van de schriftelijke wilsverklaring nog (lang) niet uitgekristalliseerd was.

Levensbeëindiging op basis van een schriftelijke wilsverklaring geldt naar het oordeel van de Nederlandse wetgever juridisch gezien als levensbeëindiging op verzoek. De schriftelijke wilsverklaring kan in de plaats komen van een mondeling verzoek van de desbetreffende patiënt en heeft volgens de wetgever dan dezelfde status als een mondeling verzoek. De wet stelt aan deze schriftelijke wilsverklaring weinig eisen. Toch is een dergelijke schriftelijke wilsverklaring sec nog niet voldoende om een beroep te kunnen doen op de strafuitsluitingsgrond zoals geformuleerd in artikel 293 lid $2 \mathrm{Sr}$. Dit blijkt ook uit de zinsnede dat de zorgvuldigheidseisen uit het eerste lid van artikel $2 \mathrm{Wtl}$ 'van overeenkomstige toepassing' zijn. De arts moet de 'algemene' zorgvuldigheidseisen in acht nemen. Het is echter niet zo dat alle eisen onverkort gelden. De zorgvuldigheidscriteria zijn volgens de wetsgeschiedenis 'zoveel als feitelijk mogelijk is in de gegeven situatie van toepassing'. ${ }^{36}$ Daar wringt de schoen: juridisch gezien is het vreemd dat in de 'lastige(re)' variant van euthanasie bij een wilsonbekwame patiënt de zorgvuldigheidseisen minder strikt hoeven te worden nageleefd dan in de 'standaardsituatie'.

Aan sommige eisen van artikel 2 lid $1 \mathrm{Wtl}$ kan de arts niet voldoen in geval van een patiënt waarmee communicatie niet of nauwelijks mogelijk is: zoals met de patiënt tot de overtuiging komen dat er voor de situatie geen redelijke andere oplossing is. Tevens is het voorlichten van de patiënt over diens situatie en vooruitzichten in de actuele situatie feitelijk niet meer mogelijk. Eventuele problematiek die zich bij de uitvoering van euthanasie op basis van een wilsverklaring kan voordoen, is door de wetgever niet voorzien. Maar ook de vrijwilligheid en weloverwogenheid van het verzoek en de uitzichtloosheid en ondraaglijkheid van het lijden van de patiënt roepen vragen op in de artikel 2 lid $2 \mathrm{Wtl}$-situatie. Hoe kan door de arts en consulent vastgesteld worden dat in de actuele situatie sprake is van een vrijwillig en weloverwogen verzoek en van ondraaglijk lijden? Wat te doen als de reeds wilsonbekwame patiënt laat merken (toch) geen euthanasie te 'willen'? Een en ander is door de wetgever overgelaten aan de arts als professional in het concrete geval die daarmee in deze lastige(re) euthanasievariant veel of zelfs te veel verantwoordelijkheid heeft gekregen. Vanuit het oogpunt van het te beschermen rechtsgoed (het menselijk leven) is dat lastig te verdedigen. Tevens komt de rechtszekerheid in het geding,

beëindiging op verzoek en hulp bij zelfdoding), Stb. 2001, 194. Inwerkingtreding 1 april 2002, Stb. 2002, 165.

36. Kamerstukken II 2000/01, 26691, nr. 35. Zie ook HR 21 april 2020, ECLI:NL:HR:2020:712, r.o. 4.4.1. 
zowel van de arts als van de patiënt die een schriftelijke wilsverklaring heeft opgesteld.

Een van de kernproblemen is dat samenspraak tussen arts en patiënt in de actuele situatie niet of nauwelijks mogelijk is, terwijl deze samenspraak voor de vaststelling of aan deze eisen is voldaan in de standaardsituatie door de wetgever juist benadrukt wordt. ${ }^{37}$ In de parlementaire wetsgeschiedenis is oog geweest voor de specifieke positie van de arts die geconfronteerd wordt met een schriftelijke wilsverklaring van een patiënt met gevorderde dementie. De ministers hebben erkend dat de situatie van de wilsonbekwaam geworden patiënt met een schriftelijke wilsverklaring op het cruciale punt, het vermogen tot wilsuiting, onvergelijkbaar is met die van de wilsbekwame patiënt. ${ }^{38}$ Het is echter niet voldoende uitgekristalliseerd welke consequenties dat heeft voor de invulling en de naleving van de zorgvuldigheidseisen door de uitvoerend arts en de consulent.

In de parlementaire geschiedenis is in zijn algemeenheid benadrukt dat in principe álle zorgvuldigheidseisen onverkort gelden en dat daarop bewust geen uitzondering is gecreëerd in de wet. ${ }^{39}$ Het handelen van de arts in de artikel 2 lid $2 \mathrm{Wtl}$-situatie aangaande een wilsonbekwame patiënt waarmee communicatie niet meer mogelijk is, betekent in feite toch een uitzondering op die regel. Maar de wetsgeschiedenis geeft er geen blijk van dat de wetgever zich dat laatste heeft gerealiseerd en de regels daarvan uitgaande heeft ingericht. De schriftelijke wilsverklaring is 'erkend', maar nadere duidelijke regels voor legitieme invulling en toepassing zijn uit de wetsgeschiedenis niet op te maken. De wetgever beschouwde de Wtl als sluitstuk van het beleid en de jurisprudentie van de jaren daarvoor: wat betreft de 'standaardsituatie' is de Wtl inderdaad te beschouwen als codificatie van een solide basis die daarvoor al min of meer praktijk was geworden. Een 'rijpingsproces' heeft wat betreft de regeling van schriftelijke wilsverklaring euthanasie echter nooit voldoende plaatsgehad. ${ }^{40} \mathrm{De}$ parlementaire geschiedenis met betrekking tot de schriftelijke wilsverklaring blijkt geen afgerond geheel, maar eerder aanleiding voor nadere discussie.

\section{Een andere benadering: de regeling van de schriftelijke wilsverklaring in België}

In België is vlak na Nederland ook een euthanasiewet in werking getreden met een regeling van de schriftelijke wilsverklaring. ${ }^{41}$ Op grond van artikel 4 van de Belgi-

37. O.a. Kamerstukken // 2000/01, 26691, nr. 24, p. 2. Zie nader Postma 2021, par. 5.2.6.

38. Kamerstukken II 1999/2000, 26691, nr. 6, p. 92.

39. Kamerstukken / 2000/01, 26691, 137b, p. 16.

40. Postma 2021, par. 7.12 en 9.4

41. Wet van 28 mei 2002 betreffende de euthanasie, BS 22 juni 2002 (inwerkingtreding 20 september 2002), in het bijzonder art. 4 sche Euthanasiewet is euthanasie op basis van een schriftelijke wilsverklaring toegestaan, echter enkel bij patiënten die onomkeerbaar niet meer bij bewustzijn zijn. In de praktijk gaat het met name om patiënten die in een toestand van onomkeerbare coma verkeren; in Nederland is de regeling van de schriftelijke wilsverklaring niet van toepassing op die situatie, vanwege het niet kunnen vaststellen dat in dat geval sprake is van 'ondraaglijk lijden' bij de patiënt. Daarentegen is euthanasie bij gevorderde dementie op basis van een schriftelijke wilsverklaring in België in principe uitgesloten. In Belgie is de keuze gemaakt om - het bijzondere en ingewikkelde van de materie onderkennend - het probleem van wilsverklaringen en mensen die nog wel bij bewustzijn zijn maar hun wil niet kunnen uiten, tijdelijk in de ijskast te zetten. ${ }^{42}$ De materie was nog niet voldoende uitgekristalliseerd om verantwoord tot wetgeving over te kunnen gaan. Volgens Distelmans werd gevreesd dat de Belgische Euthanasiewet er - bij het nader bediscussieren van de schriftelijke wilsverklaring in het kader van dementie - helemaal niet zou komen. ${ }^{43} \mathrm{Na}$ de inwerkingtreding van de Euthanasiewet zijn in België diverse wetsvoorstellen de revue gepasseerd die beogen het toepassingsbereik van de schriftelijke wilsverklaring te verruimen door de tweede voorwaarde (de patiënt is niet meer bij bewustzijn) te wijzigen. ${ }^{44}$ De huidige Belgische wetgeving heeft volgens sommigen namelijk tot gevolg dat patiënten met dementie 'te vroeg' om euthanasie verzoeken. ${ }^{45}$ Vooralsnog hebben de wetsvoorstellen om de reikwijdte van artikel 4 te verruimen niet tot wijziging van de bepaling geleid.

\section{Regeling schriftelijke wilsverklaring ook na uitspraken Hoge Raad geen rustig bezit}

De Nederlandse regeling van de schriftelijke wilsverklaring heeft ook na de inwerkingtreding van de $\mathrm{Wtl}$ regelmatig aanleiding gegeven tot discussie. De worsteling met de interpretatie van de zorgvuldigheidseisen in het concrete geval blijkt uit de oordelen van de RTE's met betrekking tot de artikel 2 lid $2 \mathrm{Wtl}$-situatie. ${ }^{46}$ Per geval

42. Postma 2021, par. 8.6.3

43. W. Distelmans, Voor ik het vergeet. Alles over het levenseinde bij dementie en wilsonbekwaamheid, Amsterdam/Antwerpen: Houtekiet 2019.

44. Zie bijvoorbeeld Parl.St. Senaat 2003-2004, 3-804/1; Parl.St. Senaat 2005-2006, 3-1485/1; Belgische Kamer van Volksvertegenwoordigers 2010-2011, Doc 53 0498/001; Belgische Kamer van Volksvertegenwoordigers 2019-2020, Doc 55 0632/001 en Belgische Kamer van Volksvertegenwoordigers 2019-2020, Doc 55 0749/001.

45. Wetsvoorstel van 13 november 2019 van Gabriels c.s. tot wijziging van de wet van 28 mei 2002 betreffende de euthanasie met het oog op het uitbreiden van de wilsverklaring voor verworven wilsonbekwaamheid. Doc 55 0749/001, p. 6

46. Postma 2021, par. 6.7 en 6.14. De oordelen van de RTE's zijn te raadplegen via: www.euthanasiecommissie.nl. 
wordt zo goed mogelijk invulling gegeven aan de wettelijke eisen, die 'zoveel als feitelijk mogelijk is' gelden. De oordelen van de RTE's zijn casuïstisch, zeer afhankelijk van de omstandigheden van het geval, waarbij wederom het beeld naar voren komt dat het huidige model, met deze zorgvuldigheidseisen, niet volstaat. $\mathrm{Na}$ de inwerkingtreding van de $\mathrm{Wtl}$ is gebleken dat artsen amper bereid zijn euthanasie uit te voeren indien communicatie met de wilsonbekwaam geworden patiënt niet of nauwelijks meer mogelijk is. Een groep artsen heeft in 2017 zelfs expliciet aangegeven geen euthanasie te willen toepassen bij een patiënt die zich daar niet van bewust is. ${ }^{47}$ Het is ook niet verrassend dat euthanasie met betrekking tot de artikel 2 lid 2 Wtl-situatie zelden voorkomt. Bovendien komt het relatief vaak voor dat een arts in de artikel 2 lid 2 Wtl-situatie volgens de RTE niet conform de zorgvuldigheidseisen heeft gehandeld. ${ }^{48}$ De wetgever heeft de arts wel de mogelijkheid gegeven om gehoor te geven aan een schriftelijke wilsverklaring euthanasie van een inmiddels wilsonbekwame patiënt, maar de normering van levensbeëindigend handelen in die situatie schiet tekort, zoals ook blijkt uit de (discussies naar aanleiding van de) koffie-euthanasiezaak.

Het valt op dat in het vonnis van de rechtbank Den Haag van 11 september 2019 en de uitspraken van de Hoge Raad van 21 april 2020 in de zogenoemde 'koffieeuthanasiezaak' het model van de regeling van de schriftelijke wilsverklaring in artikel 2 lid $2 \mathrm{Wtl}$ als een normatieve en feitelijke vanzelfsprekendheid en duidelijkheid lijkt te zijn beschouwd en de wetshistorische interpretatie centraal staat. ${ }^{49}$ De Hoge Raad heeft in zijn arrest van 21 april 2020 overwogen dat de inhoud en betekenis van de zorgvuldigheidseisen in de artikel 2 lid $2 \mathrm{Wtl}$-situatie 'in sommige opzichten een eigen invulling krijgen'. Het gaat, aldus de Hoge Raad, 'immers om de - in de wetsgeschiedenis als 'bijzonder' aangeduide - situatie waarin de nakoming van de zorgvuldigheidseisen ook compensatie moet bieden voor het onvermogen van de patiënt om nog langer zelf zijn wil te vormen en te uiten'. ${ }^{50} \mathrm{Er}$ bestaat enige spanning tussen die notie en de mogelijkheid dat de zorgvuldigheidseisen 'van overeenkomstige toepassing zijn'. Dat het een bijzondere situatie betreft waarvan de regeling compensatie moet bieden voor een gebrek aan samenspraak met de patiënt, volgt bepaald niet uit de systematiek van de wet dat volstaan kan worden met de modaliteit en de formulering dat de zorgvuldigheidseisen 'van overeenkomstige toepassing' zijn.

Daar komt nog bij dat de parlementaire geschiedenis opvattingen betreft van meer dan twintig jaar geleden. Het denken over euthanasie op basis van een schriftelij-

47. Zie www.nietstiekembijdementie.nl.

48. Postma 2021, par. 7.12 en 9.7.

49. Rb. Den Haag 11 september 2019, ECLI:NL:RBDHA:2019:9506; HR 21 april 2020, ECLI:NL:HR:2020:712; HR 21 april 2020, ECLI:NL:HR: 2020:713. Zie ook P.A.M. Mevis \& L. Postma, 'Tussenkroniek rechtspraak strafrecht', TVGR 2021, p. 280-291.

50. HR 21 april 2020, ECLI:NL:HR:2020:712, r.o. 4.4.2 en 4.4.3. ke wilsverklaring bij patiënten die niet meer in staat zijn hun wil te uiten heeft in de periode na de inwerkingtreding van de $\mathrm{Wtl}$ een ontwikkeling doorgemaakt. In onder meer de juridische literatuur is de regeling van de schriftelijke wilsverklaring dikwijls onder vuur genomen. Dat geldt bijvoorbeeld voor de beoordeling van de eis van ondraaglijk lijden, de betekenis van 'van overeenkomstige toepassing' en de vraag of, vanwege bescherming van het recht op leven, verificatie van de doodswens van de patiënt noodzakelijk is. ${ }^{51}$ Argumenten op basis van de parlementaire geschiedenis zijn (ook) wat dat laatste betreft ontoereikend, want verouderd. In de parlementaire geschiedenis kon nog geen rekening gehouden worden met uitspraken van het EHRM ter zake van artikel 2 en artikel 8 EVRM. ${ }^{52}$ Ook is in de literatuur naar voren gebracht dat bijvoorbeeld het VN-verdrag inzake de Rechten van Personen met een Handicap, waarin is bepaald dat staten de verplichting hebben noodzakelijke maatregelen te treffen om het leven van kwetsbare personen (inclusief personen met dementie) te beschermen, implicaties heeft voor de reikwijdte van artikel 2 lid $2 \mathrm{Wtl}{ }^{53}$ Voorts blijkt de veronderstelling dat een patiënt met gevorderde dementie geen levenswens heeft of zou kunnen hebben of kan vormen naar hedendaagse opvattingen niet zonder meer op te gaan. Bovendien zou, met het recent in werking getreden artikel 3 van de Wet zorg en dwang als voorbeeld, gesteld kunnen worden dat het vaststellen van wilsonbekwaamheid van een patiënt, ook - of juist - in het licht van een vergaande handeling als euthanasie (een beslissing over leven of dood), nadere regels behoeft. $^{54}$

\section{Voorstel tot wijziging}

Ondanks de in het bovenstaande genoemde bezwaren tegen de huidige regeling is het doen vervallen van de regeling van de schriftelijke wilsverklaring, zeker na de uitspraken van de Hoge Raad van 21 april 2020, politiek-maatschappelijk gezien anno 2021 niet haalbaar en in de systematiek van het recht betreffende euthanasie ook niet nodig. ${ }^{55}$ Reële alternatieven voor regeling van de schriftelijke wilsverklaring anders dan binnen de

51. Zie ook N. Rozemond, 'De juridische plicht om euthanasie te bespreken met patiënten met dementie voordat artsen schriftelijke wilsverklaringen kunnen uitvoeren', NTS 2020/4, p. 224-232.

52. EHRM 29 april 2002, Pretty t. Verenigd Koninkrijk, nr. 2346/02; EHRM 20 januari 2011, Haas t. Zwitserland, nr. 31322/07; EHRM 31 januari 2019, Fernandes de Oliveira t. Portugal, nr. 78103/14

53. Zie o.a. N. Rozemond, 'Mensen met dementie hebben het recht om euthanasie te weigeren', NJB 2020/292 en N. Rozemond, 'Het mensenrechtelijke tekort van het Nederlandse euthanasierecht', NTM/ NJCM-Bul. 2020, 3, p. 367.

54. Wet van 24 januari 2018, houdende regels ten aanzien van zorg en dwang voor personen met een psychogeriatrische aandoening of een verstandelijke handicap (Wet zorg en dwang psychogeriatrische en verstandelijk gehandicapte cliënten), inwerkingtreding 1 januari 2020 en N. Rozemond, 'Het vaststellen van wilsonbekwaamheid bij patiënten met dementie ter zake van beslissingen over het beëindigen van hun leven', TVGR 2020, p. 361-374.

55. Mevis en Postma 2021, p. 280-291. 
Wtl, doen zich niet voor. ${ }^{56}$ Noodzaak tot wijziging van de huidige regeling is er wel. Van een duidelijke, coherente achterliggende gedachteontwikkeling achter de regeling van de schriftelijke wilsverklaring is geen sprake geweest: het denken over de schriftelijke wilsverklaring is telkens als een 'bij-onderwerp' meegelift op het kader van euthanasie op basis van een actueel, mondeling verzoek. Enerzijds is het begrijpelijk dat de standaardregeling prioriteit had in het verleden. Anderzijds heeft daardoor het specifieke van euthanasie op basis van een schriftelijke wilsverklaring te weinig andacht gekregen. Beide situaties kennen te grote verschillen om de zorgvuldigheidseisen uit het ene model 'van overeenkomstige toepassing' op het andere te kunnen beschouwen.

Het blijkt noodzakelijk de regeling binnen de Wtl opnieuw, uitgebreider en apart te regelen. In het in de inleiding genoemde promotieonderzoek is daartoe een concreet voorstel gedaan, waarin artikel 2 lid $2 \mathrm{Wtl}$ komt te vervallen en een nieuw artikel $(2 \mathrm{a} \mathrm{Wtl})$ is voorgesteld:

1. Indien de patiënt van twaalf jaren ${ }^{57}$ of ouder niet langer in staat is zijn wil te uiten, maar voordat hij in die staat geraakte tot een redelijke waardering van zijn belangen ter zake in staat werd geacht een schriftelijke wilsverklaring, inhoudende een verzoek om levensbeëindiging, heeft opgesteld, kan de arts aan dit verzoek gevolg geven.

2. De zorgvuldigheidseisen, bedoeld in het tweede lid van artikel 293 Wetboek van Strafrecht houden in het geval van het eerste lid in dat de arts:

a. de overtuiging heeft gekregen dat de patiënt zijn verzoek tot levensbeëindiging in de schriftelijke wilsverklaring vrijwillig en weloverwogen heeft gedaan en de arts er zich van heeft overtuigd dat de patiënt de schriftelijke wilsverklaring blijkens het medische dossier met enige regelmaat heeft bevestigd en geactualiseerd;

b. de overtuiging heeft gekregen dat de patiënt die niet meer in staat is tot een redelijke waardering van zijn belangen ter zake, uitzichtloos lijdt aan een ongeneeslijke ziekte of aandoening en zich in een situatie bevindt die overeenstemt met de in de schriftelijke wilsverklaring en in de bevestiging en actualisering daarna als ondraaglijk lijden beschreven situatie;

c. heeft vastgesteld dat de patiënt, toen hij nog tot een redelijke waardering van zijn belangen ter zake in staat was, voldoende is voorgelicht door een arts omtrent de betekenis van de schriftelijke wilsverklaring, over de ingetreden medische situatie die aanleiding geeft om te veronderstellen dat de in de schriftelijke wilsverklaring omschreven situatie zich kan gaan voordoen en over de vooruitzichten dienaangaande;

57. In de huidige regeling is euthanasie op basis van een schriftelijke wilsverklaring ook mogelijk vanaf 12 jaar: zie art. 2 lid $4 \mathrm{Wtl}$. d. de overtuiging heeft gekregen dat er voor de situatie waar de patiënt zich in bevindt geen redelijke andere oplossing is;

e. de overtuiging heeft gekregen dat zich ten tijde van het voornemen tot en bij de uitvoering van de levensbeëindiging geen indicaties voordoen dat het verlangen tot levensbeëindiging van de patiënt niet langer aanwezig is;

f. ten minste twee andere, onafhankelijke artsen heeft geraadpleegd, die, ieder voor zich, de patiënt hebben gezien, kennis hebben genomen van de schriftelijke wilsverklaring alsmede van het medisch dossier en voorts onafhankelijk van elkaar schriftelijk hun oordeel hebben gegeven over de eisen a $\mathrm{t} / \mathrm{m} \mathrm{d}$, en advies hebben gegeven omtrent de eisen e en $\mathrm{g}$;

g. de levensbeëindiging medisch zorgvuldig heeft uitgevoerd.

3. Indien door de patiënt in de schriftelijke wilsverklaring een vertrouwenspersoon is aangewezen, bespreken de arts en de onafhankelijke artsen als bedoeld in onderdeel $\mathrm{f}$ het in de schriftelijke wilsverklaring geuite verzoek voorafgaand aan de uitvoering van het verzoek met deze vertrouwenspersoon.

4. Heeft de patiënt nog niet de leeftijd van zestien jaren bereikt dan wordt aan zijn verzoek geen uitvoering gegeven indien de ouder of de ouders die het gezag over de minderjarige uitoefent of uitoefenen dan wel diens voogd niet met de levensbeëindiging instemmen. ${ }^{58}$

In dit voorstel tot wijziging is de basis nog steeds het besluitvormingsproces van de arts op verzoek van de patiënt, vanuit de opvatting dat levensbeëindiging op basis van een schriftelijke wilsverklaring levensbeëindiging op verzoek van de patiënt is. Het recht moet het in geval van een schriftelijke wilsverklaring echter doen met een vermoeden van een uitdrukkelijk en ernstig verlangen in de zin van artikel 293 lid $1 \mathrm{Sr}$. Dat kan juridisch gezien voldoende zijn, maar er vloeit wel een antal eisen en criteria uit voort. Niet alleen om de arts te ondersteunen, maar om bescherming van het fundamentele recht op leven van de kwetsbare patiënt die niet of nauwelijks in staat is zijn wil te uiten, te kunnen waarborgen.

Het vaststellen dat de schriftelijke wilsverklaring een vrijwillig en weloverwogen verzoek van een op het moment van optekenen wilsbekwame patiënt representeert, is de ondergrens om in een later stadium tot euthanasie over te kunnen gaan. Dat is nog niet voldoende. Er dient een 'boog' te kunnen worden gespannen vanaf de schriftelijke wilsverklaring tot in de actuele situatie van de patiënt, om in de actuele situatie het vermoeden van het verlangen tot levensbeëindiging in stand te kunnen houden en daaraan legitiem (toch) gehoor te geven. Gesprekken tussen de (wilsbekwame)

58. Postma 2021, par. 9.22 
patiënt en de arts zijn onontbeerlijk om een brug te slaan tussen de schriftelijke wilsverklaring en uiteindelijk de actuele situatie van de patiënt. De patiënt kan zijn wensen en angsten uiten die hem hebben doen besluiten de schriftelijke wilsverklaring op te stellen. De arts kan daarop inspelen en de patiënt, toegespitst op de diagnose en prognose van de patiënt, informeren over alternatieven die naar aanleiding van de situatie van de patiënt bestaan naast het ultimum remedium euthanasie. Op basis van de gesprekken kan de patiënt de tekst van de schriftelijke wilsverklaring eventueel verfijnen c.q. aanpassen. De arts dient van het gesprek, en de daaropvolgende gesprekken, een aantekening in het medisch dossier van de patiënt te maken, zodat ook later is aan te tonen dat bespreking van de wensen rondom het levenseinde van de patiënt en de eventuele rol van de wilsverklaring euthanasie, heeft plaatsgevonden. ${ }^{59}$

Idealiter is de arts die de levensbeëindiging (eventueel) uitvoert, ook de arts die in het verleden, toen de patiënt daartoe nog in staat was, met de patiënt over de schriftelijke wilsverklaring heeft gesproken. De arts weet dan mede op grond van zijn eigen wetenschap uit de communicatie met de patiënt wat de bedoelingen van de patiënt zijn geweest, wat de patiënt in de toekomst nog wel aanvaardbaar zou vinden en wat de patiënt beslist niet zou willen. En hij heeft de gelegenheid gehad om bij enige twijfel daarover een en ander bij de patiënt na te vragen. De uitvoerend arts beschikt dan (zelf) over het 'complete plaatje'. Dat draagt mogelijk ook bij aan de zorgvuldigheid en acceptatie van de beslissing van de arts om überhaupt gevolg te geven aan een in een schriftelijke wilsverklaring geuit euthanasieverzoek. Een behandelrelatie tussen uitvoerend arts en patiënt is om praktische redenen echter niet altijd meer mogelijk. Bovendien kan de arts die destijds de gesprekken met de patiënt heeft gevoerd, om wat voor reden dan ook weigeren euthanasie uit te voeren. Het bestaan van een zekere behandelrelatie is dan ook niet als zorgvuldigheidseis opgenomen in het voorstel tot wijziging van de regeling. ${ }^{60}$ Wel dient de uitvoerend arts de overtuiging te hebben dat de patiënt de schriftelijke wilsverklaring met enige regelmaat heeft bevestigd en geactualiseerd. De uitvoerend arts kan het medisch dossier van de patiënt gebruiken om te beoordelen, en na uitvoering van euthanasie te onderbouwen, dat sprake was van een vrijwillig en weloverwogen verzoek van de patiënt. Is de weergave van de wens van de patiënt in het medisch dossier te minimaal om tot naleving van de zorgvuldigheidseis te komen, dan betekent het enkele feit dat er een schriftelijke wilsverklaring aanwezig is niet dat er ook sprake is van een vrijwillig en weloverwogen verzoek. Is er, blijkens het medisch dossier, een duidelijke contactboog te zien tussen het moment van diagnose en de actuele situatie, en heeft de patiënt daarin regelmatig het verzoek bevestigd of geactualiseerd, dan zal de uitvoerend arts meer aanknopingspunten hebben om in de

59. Zie nader Postma 2021, par. 9.13-9.14

60. Postma 2021, par. 9.14. actuele situatie overtuigd te kunnen zijn van het verlangen tot levensbeëindiging van de patiënt. Uitvoering van de euthanasie is vervolgens eerder gelegitimeerd..$^{61}$

Ook bevindingen in de actuele situatie spelen een belangrijke rol. De uitvoerend arts dient de overtuiging te hebben dat de patiënt uitzichtloos lijdt aan een ongeneeslijke ziekte of aandoening en zich in een situatie bevindt die overeenstemt met de in de schriftelijke wilsverklaring en in de bevestiging en actualisering als ondraaglijk lijden beschreven situatie. De uitvoerend arts dient met andere woorden vast te stellen wat de patiënt, gezien de inhoud van zijn schriftelijke wilsverklaring en de bevestiging daarvan na een bepaalde diagnose, als ondraaglijk lijden beschouwde. Vervolgens dient de arts te beoordelen of die omstandigheid van door de patiënt omgeschreven ondraaglijk lijden zich voordoet en of er daarbij sprake is van uitzichtloos lijden (in de zin van een niet behandelbare medisch geclassificeerde ziekte of aandoening). Hoe concreter de inhoud van de schriftelijke wilsverklaring is op het punt van ondraaglijk lijden, hoe meer aanknopingspunten de arts zal hebben om er in de actuele situatie van overtuigd te kunnen zijn dat daarvan sprake is. Grondslag voor het handelen van de arts is niet de moeilijk vast te stellen ondraaglijkheid van het lijden van de patiënt, maar meer het voorkomen van (verdere) ontluistering van het menselijk leven van de patiënt uit respect voor de wens van de patiënt die een dergelijk verzoek, vanwege toekomstig ondraaglijk lijden, in de schriftelijke wilsverklaring heeft opgetekend. ${ }^{62}$

Om een zorgvuldig besluitvormingsproces te bevorderen dient de arts ten minste twee andere, onafhankelijke artsen te hebben geraadpleegd. Het is aangewezen dat ten minste een van de consulenten een specifieke deskundigheid ter zake heeft. ${ }^{63}$ Daarnaast is in het voorstel tot wijziging van de regeling de rol van een vertrouwenspersoon wettelijk verankerd. De vertrouwenspersoon kan de arts wijzen op het bestaan van de schriftelijke wilsverklaring en aangeven dat de actuele situatie geïnterpreteerd kan worden als het moment waarop de patiënt euthanasie zou willen. Voorts kan de vertrouwenspersoon de wil van de patiënt en de bedoelingen van de patiënt met diens schriftelijke wilsverklaring nader toelichten. De vertrouwenspersoon kan de uitvoerend arts zodoende helpen om te bepalen of zich inderdaad de situatie voordoet waarin de patiënt blijkens de wilsverklaring zou willen dat zijn leven zou worden beëindigd. De beslissing om tot levensbeëindiging over te gaan en de vaststelling of aan de zorgvuldigheidseisen is voldaan is aan de uitvoerend arts. De opvattingen van de vertrouwenspersoon zijn niet doorslaggevend. Diens opvattingen gelden niet als de wil van de patiënt, maar

\footnotetext{
61. Postma 2021, par. 9.14.

62. Postma 2021, par. 9.16

63. Postma 2021, par. 9.20. Zie ook HR 21 april 2020, ECLI:NL:HR: 2020:712, r.o. 4.9.
} 
fungeren ter ondersteuning van het interpreteren van de wil van de patiënt. ${ }^{64}$

Indien zich ten tijde van het voornemen tot levensbeëindiging en bij de uitvoering ervan indicaties voordoen dat het verlangen van de patiënt niet langer aanwezig is, is euthanasie in de zin van artikel 293 lid $1 \mathrm{Sr}$ (in ieder geval op dat moment) uitgesloten. Van een contraindicatie is sprake indien de patiënt zegt 'niet dood te willen' of uitingen doet die geinterpreteerd kunnen worden als 'niet-willen-sterven' of zelfs als levenswens. De arts dient de levensbeëindiging in geval van een dergelijke contra-indicatie (vooralsnog) te staken. Het vermoeden van de doodswens van de patiënt komt te vervallen. Dat is het gevolg van de eis van bescherming van het recht op leven, óók het leven van de kwetsbare, wilsonbekwaam geworden patiënt. Vanuit het oogpunt van eerbiediging van het menselijk leven en het recht op leven kan gesteld worden dat ook de patiënt met gevorderde dementie euthanasie alsnog kan of zou moeten kunnen tegenhouden. Een patiënt kan geen afstand doen van het recht op leven noch de arts van de plicht dat recht te respecteren. ${ }^{65}$ Het risico om tegen de 'wil' van de patiënt in de actuele situatie levensbeëindigend te handelen is vanwege het definitieve aan het handelen te groot om bij twijfel over de doodswens van de patiënt euthanasie toch - althans op dat moment - doorgang te doen vinden. In geval van een contra-indicatie in de actuele situatie komt het vermoeden dat sprake is van een uitdrukkelijk en ernstig verlangen van de patiënt zodoende te vervallen: artikel $293 \mathrm{Sr}$ kan dan niet meer van toepassing zijn. Andersom is het, als tegenargumenten voor het bestaan van een verlangen uitblijven, rechtens gelegitimeerd om een voorwaardelijk verzoek als vermoeden van een verlangen tot levensbeëindiging te beschouwen. Indien de schriftelijke wilsverklaring geactualiseerd is, blijk geeft van een consistente wil van de patiënt en zich in de actuele situatie geen indicaties voordoen dat het verlangen van de patiënt niet langer aanwezig is, blijft het vermoeden van de wil van de patiënt intact. ${ }^{66}$

\section{Tot slot}

Euthanasie is ingewikkeld, voor euthanasie op basis van een schriftelijke wilsverklaring geldt dat des te meer. Dat het om moeilijke en zeldzame zaken gaat, verandert niet met een gewijzigde regeling. Juridisch gezien wringt de huidige regeling, waardoor er noodzaak tot wijziging is, ook met het oog op de verwachting dat in de toekomst meer mensen dementie krijgen en meer mensen na de diagnose dementie een schriftelijke wilsverklaring zullen opstellen.
Er kan niet worden volstaan met de normen van artikel 2 lid $1 \mathrm{Wtl}$ bij deze lastigere variant. Euthanasie op basis van een schriftelijke wilsverklaring is een dermate andere situatie dan euthanasie op basis van een actueel, mondeling verzoek van een ondraaglijk lijdende patiënt dat die situatie - ook normatief - andere regels verlangt dan de 'standaardsituatie'. Eigen voorwaarden en procedures zijn aangewezen om compensatie te bieden voor de afwezigheid van samenspraak met de patiënt over de zorgvuldigheidseisen in de actuele situatie. Niet alleen om de arts te ondersteunen, maar ook om bescherming van het fundamentele recht op leven van de kwetsbare patiënt, die niet of nauwelijks in staat is zijn wil te uiten, te kunnen waarborgen.

\footnotetext{
64. Postma 2021, par. 9.16

65. Postma 2021, par. 9.17.

66. Postma 2021, par. 9.12 en 9.17
} 